\title{
Occurrence of the bentfin devil ray, Mobula thurstoni (Chondrichthyes: Mobulidae), in the western Atlantic
}

\author{
Otto Bismarck Fazzano Gadig**, Rafael Cabrera Namora* ${ }^{\dagger}$ and Fábio dos Santos Motta* ${ }^{\dagger}$ \\ *Universidade Estadual Paulista, \\ Campus do Litoral Paulista, Praça Infante dom Henrique, s/n, Parque Bitarú, 11330-900, São Vicente—SP, Brazil. ${ }^{\dagger}$ Universidade \\ Estadual Paulista, Instituto de Biociências, Departamento de Zoologia; Av. 24-A, 1515, 13506-900, Rio Claro-SP, Brazil. \\ ${ }^{\ddagger}$ Corresponding author, e-mail: gadig@bignet.com.br
}

\begin{abstract}
This paper reports the occurrence of the fifth species of Mobula in the western Atlantic, M. thurstoni, based on specimens caught by artisanal and driftnet fisheries in coastal waters off southern Brazil.
\end{abstract}

The elasmobranch family Mobulidae includes two genera of medium to large sized pelagic rays, distributed in all tropical and subtropical oceans. Devil rays, genus Mobula, comprise nine poorly known species, measuring from 1 to about $4 \mathrm{~m}$ of disc width. Four species were previously recorded in the western Atlantic. Mobula hypostoma, from coastal areas off North Carolina, USA to Mar del Plata, Argentina, including the Brazilian coast, Caribbean and Gulf of Mexico (Figueiredo, 1977); Mobula rochebrunei, reported in the western Atlantic, based on an adult female caught in a coastal area off southern Brazil in 1989 (M. Barletta, personal communication); Mobula tarapacana, observed during aerial surveys carried out in the Venezuelan coast (Notarbartolo-di-Sciara \& Hillyer, 1989) and in the Brazilian coast (Gadig \& Sampaio, unpublished data); and Mobula japanica, recorded along the Brazilian coast (Gadig \& Sampaio, unpublished data).

All specimens were collected in São Paulo State coasts, southeastern Brazil. The following samples were analysed: (1) three fresh specimens, adult males, $1690 \mathrm{~mm}$ in disc width (DW), 1840 mm DW and 1850 mm DW, Itanhaém City, São Paulo State, Brazil ( $\left.24^{\circ} 11^{\prime} \mathrm{S} 46^{\circ} 47^{\prime} \mathrm{W}\right), 15$ January 2000 . These specimens were collected during a study on elasmobranchs landed by the artisanal fisheries in south São Paulo coast (PROJETO CAÇÃO). The $1690 \mathrm{~mm}$ DW specimen is illustrated in the Figure 1. Fishing gear utilized was bottom monofilament gill-nets, about $1200 \mathrm{~m}$ long and $2 \mathrm{~m}$ height, mesh sizes between 7 and $12 \mathrm{~cm}$. Nets strung from 5 to 8 nautical miles from the shore, $8-15 \mathrm{~m}$ depth; (2) a juvenile male, $910 \mathrm{~mm}$ DW, Bertioga City, north

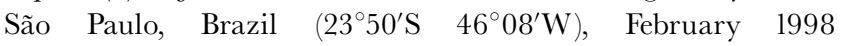
(NUPEC.439). Parts of upper and lower tooth plates and branchial filter plates were removed (NUPEC.1577), as well as the digestive tract (NUPEC.1579) for observation of food items.

Notarbartolo-di-Sciara (1987) arranged all Mobula species in six groups, according to some morphological and morphometric characters. Mobula thurstoni is unique in exhibiting the following characters: medium-sized rays, sexual maturity attained at about $1.5 \mathrm{~m} \mathrm{DW}$; base of tail (just posterior to insertion of caudal) depressed dorsally; cephalic fins short; anterior margin of the pectorals concave proximally, then convex toward apex (also cited as double curvature of the anterior margin of the pectoral); the tip of dorsal fin is white; teeth tesselated or slightly imbricated. All these characters were found in the specimens examined here.

The following additional features were observed, allowing confirmation of the species identification: head dorsally depressed, not so high in lateral view; rostral outline straight, slightly concave near the cephalic fin insertions; small sub-circular spiracle, located ventrally to the plane of pectoral fins origin; presence of a dermal mid-dorsal ridge from nuchal area to dorsal fin; mouth floor with four ridges, two in the midline and one on each side of oral cavity; no caudal spine; dorsal colour pattern bluish dark, with purple hues; a rectangular light grey area in the nuchal region, between pectoral fins origins; a narrow subtriangular bronze area along the anterior margin of the pectoral fins, between origin and apex; and a white hue along the leading edge of anterior margin of the pectoral fin, fading towards apex.

The taxonomic and morphological aspects of the branchial filter plates in Mobulidae have been discussed by Notarbartolodi-Sciara (1987). The terminal lobe with leaf-shape, lacks a longitudinal ridge, which sometimes can be found in other specimens (Notarbartolo-di-Sciara, 1987). The branchial filter plates examined in the preserved $910 \mathrm{~mm}$ DW immature male specimen presents the same basic gross morphology to that of the adult. In the specimens examined here, each face of the third branchial arch has about 70-75 plates, with 15-20 lateral lobes.

Fifteen other specimens were caught in the same area between 14 and 24 January, but they were discarded alive or consumed. These rays are not usually landed due to the difficulty in hauling such large and heavy animals into the small fishing vessels. The identity of these 15 specimens is regarded here as $M$. thurstoni due to: (1) relative high number of specimens reported for the area in a short time period; (2) specimens were described by fishermen as large individuals (some of them adult males) measuring at least $1500 \mathrm{~mm}$ DW; and (3) several photographs examined from two of these specimens, clearly depict two adult males of $M$. thurstoni.

All fresh specimens had well developed claspers, with haemorrhagic surface tissue, and basal area of the claspers as well as the pelvic fins swollen and congested. These characters may indicate mating activity in the area.

Stomach contents from the three fresh specimens showed digested small crustaceans, probably from zooplankton. Stomach contents volume varying between 95 and $215 \mathrm{ml}$. Analysis of the stomach from the preserved specimen revealed Euphausiacea as the main food item, comprising $150 \mathrm{ml}$.

Devil rays are surface water dwellers, where they prey on small planktonic crustaceans. The remarkable intensity of the silvery pattern of the preoral and cephalic fins, as observed in the present specimens, may be attractive to these organisms, 


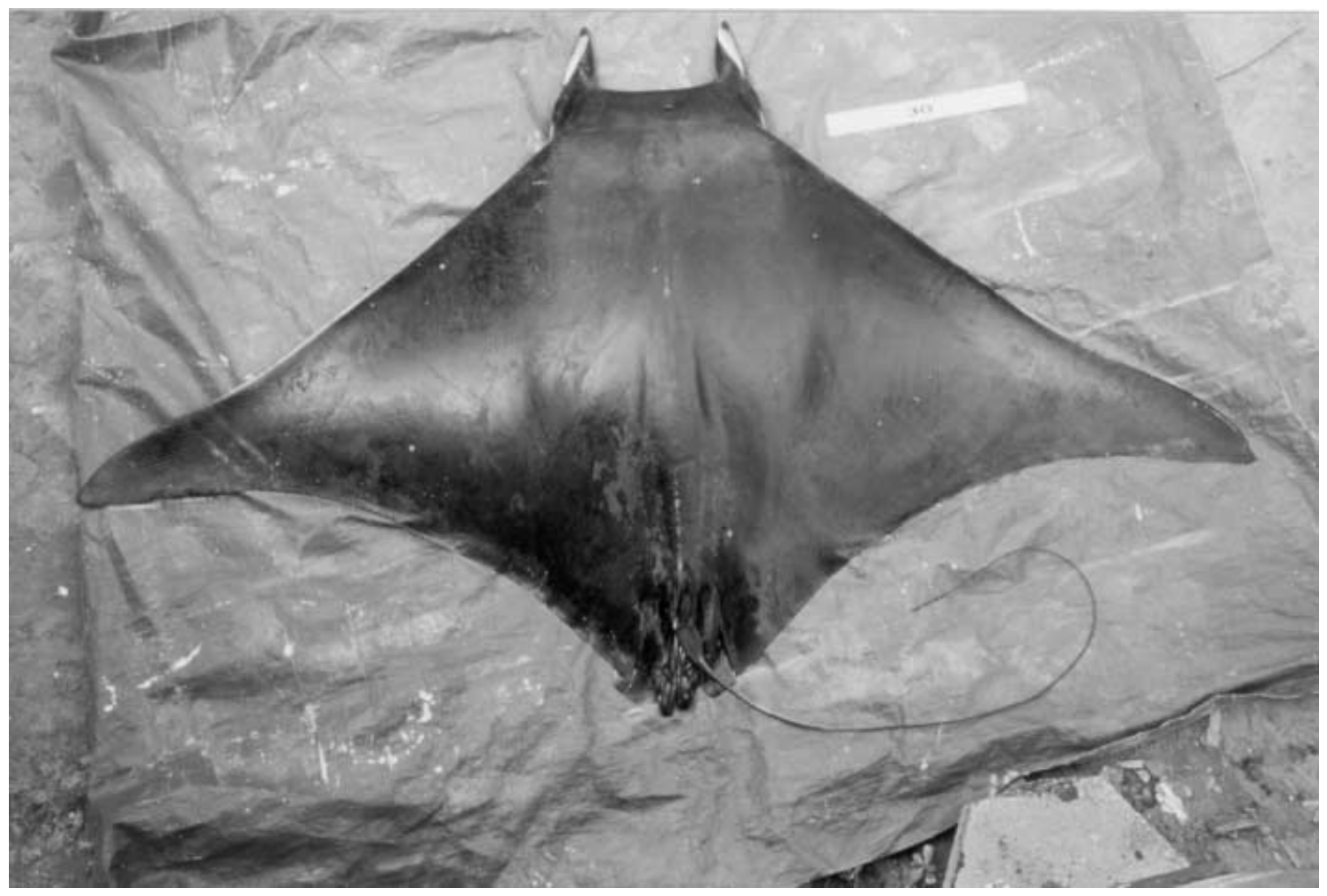

Figure 1. Mobula thurstoni, adult male, $1690 \mathrm{~mm}$ in disc width (DW), São Paulo coast.

and probably visible when the rays are swimming under low light condition. Out of water, the silvery pattern becomes more intense under bright sunlight. Also, the different mosaic and intensity of the silvery areas exhibited among Mobula species suggest a social significance, possibly intraspecific recognition, since different species can occur sintopically. The relationships between these silvery patterns with feeding or social interactions is suggested for another plankton-eater elasmobranch, the megamouth shark, Megachasma pelagios (Nakaya et al., 1997).

The occurrence of Mobula thurstoni in a coastal area off São Paulo State during the summer may be explained by the intrusion of the South Atlantic Central Water (SACW) over the continental shelf of southern Brazil. This penetration allows a remarkable high primary productivity (Matsuura, 1990), creating trophic conditions adequate to the occurrence of mobulid rays, which are associated with highly productive areas. The SACW retreats to the continental shelf border during the winter, and possibly this species follows such retraction. The presence of large specimens of $M$. thurstoni was recorded in offshore areas bordering the continental shelf of southern Brazil during the winter (O.B.F. Gadig, unpublished data). Thus, we suggest that $M$. thurstoni is frequent along the western South Atlantic, and that its distribution and abundance in the continental shelf of southern Brazil is related to the intensity of the SACW intrusions.

The authors wish to thank M.R. Oliveira (Instituto Oceanográfico, Universidade de São Paulo) for the identification of the zooplankton items from the stomach of specimens; C. Magenta da Cunha and M.M.B. Gonzales (Núcleo de Pesquisas e Estudos em Chondrichthyes, Santos, São Paulo), for giving us access to the preserved specimen.

\section{REFERENCES}

Figueiredo, J.L., 1977. Manual de Peixes Marinhos do Sudeste do Brasil, I. Introdução. Cações, Raias e Quimeras. São Paulo: Museu de Zoologia, Universidade de São Paulo.

Matsuura, Y., 1990. Rational utilization of coastal ecosystem in tropics: integrated investigation of coastal ecosystem in Ubatuba region. In Segundo Simpósio de Ecossistemas da Costa Sul e Sudeste Brasileira. Estrutura, Função e Manejo, Águas de Lindóia, São Paulo, 6-11 April 1990 (ed. S. Watanabe et al.), pp. 47-52. São Paulo: Academia do Estado de São Paulo.

Nakaya, K., Yano, Y., Takada, K. \& Hiruda, H., 1997. Morphology of the first female megamouth shark, Megachasma pelagios (Elasmobranchii: Megachasmidae), landed at Fukuoka, Japan. In Biology of the megamouth shark (ed. K. Yano et al.), pp. 51-62. Tokyo: Tokai University Press.

Notarbartolo-di-Sciara, G., 1987. A revisionary study of the genus Mobula Rafinesque, 1810 (Chondrichthyes: Mobulidae) with the description of a new species. Zoological Journal of the Linnean Society, 97, 1-91.

Notarbartolo-di-Sciara, G., 1988. Natural history of the rays of the genus Mobula in the Gulf of California. Fishery Bulletin, 86, 45-66.

Notarbartolo-di-Sciara, G. \& Hillyer, E.V., 1989. Mobulid rays off eastern Venezuela (Chondrichthyes, Mobulidae). Copeia, 3, $607-614$.

Submitted 6 November 2001. Accepted 22 May 2003. 